\title{
REGIONALISATION OF NEEDS TO REDUCE GHG EMISSION FROM AGRICULTURE IN POLAND
}

\author{
Mariusz Kistowski • Paweł Wiśniewski \\ Faculty of Oceanography and Geography \\ University of Gdańsk \\ Bażyńskiego 4, 80-309 Gdańsk: Poland \\ e-mails: mariusz.kistowski@ug.edu.pl (corresponding author)・pawel.wisniewski@ug.edu.pl
}

\begin{abstract}
An important element in the local shaping of a low-carbon economy, as well as one of the key areas of activity in communal plans for its development should be rural areas and their related agricultural activities. This is due on the one hand to the significant share of agriculture in total greenhouse gas (GHG) emissions in Poland (on average about $8 \%$, locally as much as $20-50 \%$ ), and on the other hand to the high potential of rural areas to use their resources to increase carbon sequestration in biomass and soil, reduce GHG emissions, as well as use agricultural activity for the development of renewable energy. The paper, based on the results of mathematical modelling of GHG emission from agricultural sources in all Polish communes, attempts to regionalize the needs of integrating agriculture and rural areas into the development of low-carbon economy at the local level. For this purpose, the guiding factors for regionalisation of the needs for mitigation actions were determined, and a regionalisation of these needs as well as a typology of the distinguished regions were, consequently, developed. The regions with the most urgent needs for mitigation actions were indicated, as well as the directions of mitigation actions for particular types of regions.
\end{abstract}

\section{Key words}

Agriculture • rural areas • mitigation of GHG emissions • Polish communes • low-carbon economy

\section{Introduction}

Agriculture has been identified as one of the main contributors to atmospheric greenhouse gases (GHGs) on a global scale with about $14 \%$ of global GHG emissions coming from this sector (IPCC 2013). According to Richards, Wollenberg, Buglion-Gluck, (2015), agriculture contributes an average of $30 \%$ of countries' total GHG emissions. This is higher than the IPCC global estimate of agriculture's contribution to emissions because of the large number of countries where agricultural emissions are low but relatively important in national greenhouse gas budgets. According to these authors, in 42 countries, agriculture contributes more than half of GHG emissions. In 91 countries 
agriculture contributes $\geq 20 \%$ of greenhouse gas emissions. According to the data presented in the Poland's National Inventory Report 2019 (KOBiZE 2019), the total share of GHG emissions from agriculture in Poland is $7.7 \%$. It is slightly lower than in many other European countries (in the EU, an average of $10.1 \%$ of greenhouse gases come from agricultural sources), which results from the fact that the Polish economy is based on coal and the role of energy industries in total emissions. It should be stressed, however, that agriculture in Poland is the source of $29.3 \%$ of national methane emissions and $78.6 \%$ of nitrous oxide emissions (KOBiZE 2019). According to the authors earlier research on the assessment of GHG emissions from agriculture at local level in Poland (Wiśniewski, 2018; Wiśniewski \& Kistowski, $2018,2019)$, the share of this sector in total GHG emissions is on average $8.9 \%$, howev$\mathrm{er}$, in some Polish communes amounts to as much $20-50 \%$. There is, therefore, an urgent need to draw attention to the role and importance of agriculture and rural areas in the development of low carbon economy at the local level, and to identify activities in these areas, aiming at reduction of greenhouse gas emissions and improvement of the ability to absorb $\mathrm{CO}_{2}$, which can be broadly applied in the planning of low carbon development of communes.

Based on the results of mathematical modelling of GHG emissions from agricultural sources carried out earlier by the authors in all Polish communes and its presentation using GIS (Wiśniewski \& Kistowski, 2019), this paper attempts to regionalize the needs of including agriculture and rural areas in the development of low-carbon economy at the local level. For this purpose, the guiding factors for the regionalisation of the needs of mitigation measures were determined, and a regionalisation of these needs as well as a typology of the distinguished regions were developed. The regions with the most urgent needs for mitigation actions were identified and best practice models were developed.

\section{Data and methods}

In order to assess the volume of GHG emissions from agricultural sources, conducted for all communes in Poland, a simplified methodology was used, widely described in earlier works of the authors (Wiśniewski \& Kistowski, 2018, 2019) and implemented in the Pilot programme of low carbon development of Starogard county in Pomeranian Voivodeship (Instytut na rzecz Ekorozwoju, 2015). The proposed solution is in line with the methodology and standard indicators of the Intergovernmental Panel on Climate Change (IPCC 2000, 2006), and in order to obtain more accurate emissions data, the method takes into account the elements of national methodology and emission factors developed by the National Centre for Emission Management (KOBiZE) for the purposes of preparing annual inventory reports. In order to estimate carbon footprint from agriculture in the Polish communes, the three main sources of GHG emissions from this sector in Poland were taken into account. These include: enteric fermentation of livestock (the main source of methane emissions), animal faeces (a source of methane and nitrous oxide emissions) and management of agricultural soils (a source of emissions of nitrous oxide). The burning of plant residues was also included (a source of methane and nitrous oxide emissions), although its share of GHG emissions is significantly lower. In order to estimate emissions from agricultural sources, the results of the National Agricultural Censuses (NAC) were used. These data are available from the Local Data Bank of the Central Statistical Office (LDB CSO) for 2010 and were used with regard to livestock (with distinction for dairy cows, other cattle, horses, pigs and poultry). In estimating $\mathrm{CH}_{4}$ and $\mathrm{N}_{2} \mathrm{O}$ emissions from enteric fermentation and livestock manure, the burning of plant residues and use of agricultural soils, the latest indicators were applied, as specified in the national inventory report (KOBiZE, 2019) as well as default indicators recommended by the IPCC (2006). 
Updated default indicators, compliant with the guidelines of IPCC (2006) have also been used in case of: nitrous oxide emissions in the estimation of emissions from mineral fertilizers as well as in the calculation of nitrogen mass introduced into the soil as a result of biological binding by Fabaceae plants and plant residues, share of nitrogen in faeces left by grazing animals on soils, and $\mathrm{N}_{2} \mathrm{O}$ emissions from nitrogen leaching from the soil. In order to harmonize the results and conduct comparative analyses, GHG emissions from the various types of agricultural activity, expressed in carbon dioxide equivalent $\left(\mathrm{CO}_{2}\right.$ eq) and assuming the global warming potential (GWP) the IPCC Fifth Assessment Report (IPCC, 2013), were estimated.

The first stage of the works involved conducting a typology of communes due to the total GHG emissions from the four source groups mentioned above. The typology was carried out using the Statistica software, employing the k-means method. Initially, the number of types was adopted based on a dendrogram generated by Ward's method. K-means and Ward's methods have, previously, been widely used for many years to cluster analysis, such as, in agricultural economics, analysis of socio-economic phenomena (including the functional structure of communes) and regional studies (Gaczek, Helpa, \& Kasprzyk, 1980; Rutkowski, 1982; Ossowska, 2006; Kisielińska, 2009; Szczuciński, 2017), thus, the decision for their use in this paper. The statistical influence of particular emission sources on the typology results was diversified and resulted from their share in the total emission from agriculture in Polish communes. In the case of enteric fermentation, it amounted to $41.24 \%$, the use of agricultural soils $40.08 \%$, animal faeces $18.65 \%$, and combustion of plant residues to only $0.02 \%$.

In order to delimit regions featuring maximum similarity of the types of communes belonging to them and separated due to the size of GHG emission from agriculture, an analysis of spatial distribution of these types was conducted. During the delimitation process, it was assumed that the region should consist of at least 4 communes. Exceptions to this rule apply only to border regions that may continue beyond the borders of Poland and the Wierzchowo commune, which is unique in comparison to other communes, where GHG emission is generated many times higher than its value in each of the remaining communes, amounting to $0.85 \%$ of the national emission. Only Wierzchowo constitutes a region consisting of one commune. Delimitation of regions was carried out using induction methods commonly used for regionalisation (Richling 1976; Przewoźniak 1987; Kistowski, Myga-Piątek, \& Solon, 2018), assuming that the similarity of types of communes included in their composition is maximally high and also maximally different from the types of communes adjacent to the region. There are situations where the composition of regions (especially their central parts, not adjacent to borders) includes communes of significantly different types than those dominated by them, however, they are less than 4 in number and do not qualify for a separate region.

When attempting to identify regions with the highest priority for action in terms of reducing GHG emissions, it was assumed that regions with emissions exceeding 1 million $\mathrm{Mg} \mathrm{CO}$ eq (carbon dioxide equivalent) annually have the highest priority for action, and regions with emissions between 0.5 and 1 million $\mathrm{Mg} \mathrm{CO}_{2}$ eq - a high priority. It was also assumed that the priority of mitigation measures results from the emission indicators per capita or area. The highest priority for action was given to regions where annual emissions exceed $4 \mathrm{Mg} \mathrm{CO}$ eq per capita or $250 \mathrm{Mg} \mathrm{CO}_{2}$ eq per $\mathrm{km}^{2}$, and the high priority to regions where emissions exceed 2-4 $\mathrm{Mg} \mathrm{CO}$ eq per capita or $150-250 \mathrm{Mg} \mathrm{CO}_{2}$ eq per $\mathrm{km}^{2}$.

In order to determine the share of the main groups of $\mathrm{GHG}$ emission sources in the regions and to indicate the regularity in this respect, which formed the basis for the proposal of the groups of measures recommended for use in order to reduce GHG emission, 
a typology of regions was conducted due to the structure of emissions. It included the following stages:

1. Calculation of the percentage share of GHG emissions from particular source groups. Emissions from combustion of plant residues were negligible and maximally amounted to about $0.1 \%$ of total emissions in the region, therefore, they were further omitted.

2 Dividing the share of emission (0-100\%) into ranges and assigning to these ranges ordinal numbers ranging from 7 being the highest share to 0 the lowest, which were then used in the typology:

- > 75\% (over 3/4) - very high share (7)

- 75-66.67\% (3/4-2/3) - high share (6)

- 66.66-50.01\% (2/3-1/2) - significant share (5)

- 50-33.34\% (1/2-1/3) - medium share (4)

- 33.33-20.01\% (1/3-1/5) - mediocre share (3)

- 20-10.01\% (1/5-1/10) - low share (2)

- $10-1 \%(1 / 10-1 / 100)$ - very low share (1)

- < 1\% (below 1/100) - negligible share (0).

3. The allocation of figures (in brackets) corresponding to the share of emissions from the use of agricultural soils, enteric fermentation and animal excreta to regions (e.g. 442 denotes medium share of emissions from both soil use and enteric fermentation and a low share from animal excreta).

4. Obtaining several 20 three-digit sequences denoting the share of emissions from particular groups, on the basis of which, after analysing their similarity, 12 sequences characterising the types of regions were identified. The combination of 12 sequences was aimed at improving the readability of the final typology. Grouping different sequences into one type of region, it was assumed that only two sequences can belong to one type, and the assessment value from individual emission sources of the rarer sequence may differ by a maximum of 1 point in relation to the assessment of the dominant sequence in the type.

The last stage of the work was to assign appropriate directions of mitigation actions to the designated types of regions. Three levels of urgency were determined: very urgent, urgent and average urgent. Differentiating them according to the structure and size of GHG emissions into individual sources will increase the effectiveness of local low-carbon policies and optimise the costs of reducing emissions.

\section{Results and discussion}

The cut-off level of the dendrogram, prepared for cluster analysis, indicated that it was advisable to adopt 9 types of communes owing to the amount of absolute emissions from agricultural sources. Assuming that the impact of the emission of each of the four considered groups of sources is identical (standardized data), the cut-off level of the dendrogram indicated that it was advisable to adopt 12 types of communes (Fig. 1). This article adopts the first solution (Tab. 1; Fig. 2):

I. Highest emission from animal faeces and the use of agricultural soils, very high emission from enteric fermentation and high emission from combustion of plant residues (in comparison to other communes) - zero standard deviation and coefficient of variation due to the fact that only one commune (Wierzchowo in Pomerania) was included in this type.

II. Highest emission from the use of agricultural soils, very high emission from combustion of plant residues (in comparison to other communes) and average emission from enteric fermentation and animal excreta - the type constitutes primarily the average power of agricultural soil use and low combustion of plant residues; in the case of other variables, the coefficient of variation is high (from 78 to 112). As many as 8 out of 10 communes of this type are located in the Hrubieszów area.

III. Very high emission from enteric fermentation, animal excreta and the use of agricultural soils and below average from combustion of plant residues - the type is strongly constituted by emission from enteric fermentation and the use of agricultural soils and average emission from animal excreta. As many as 30 out 

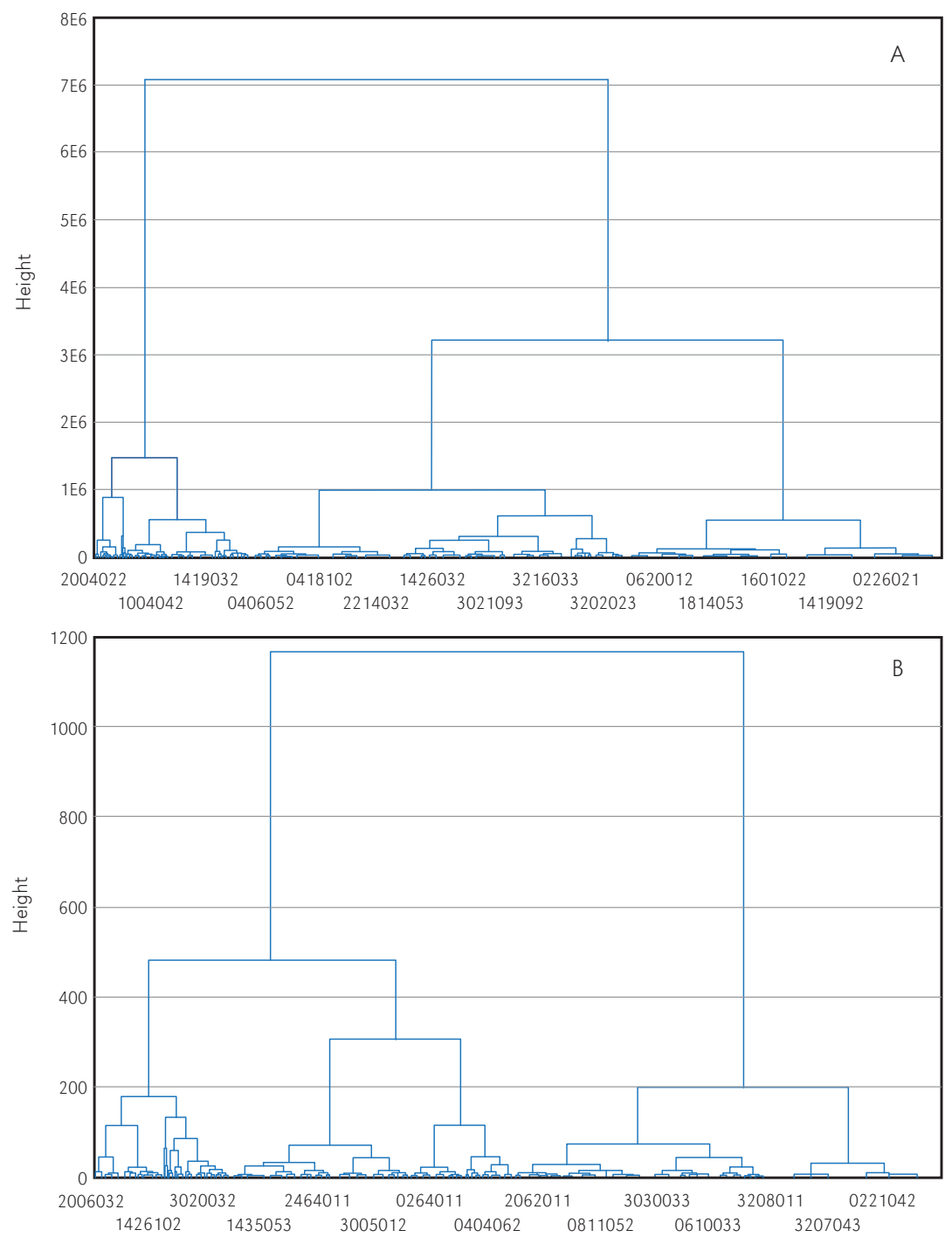

Figure 1. Dendrograms obtained using Ward's method illustrating groups of communes by the GHG emissions from agriculture, prepared on the basis of absolute data (A) and standardized data (B)

of 35 communes belonging to this type of communes are located in Podlachia and northern Mazovia.

IV.Very high emission from animal excreta and the use of agricultural soils as well as high emission from enteric fermentation and combustion of plant residues (in comparison to other communes) - the type is strongly constituted by emission from enteric fermentation and average emission from the use of agricultural soils. Among 102 communes of this type, the largest compact area is located in Podlachia and northern Mazovia, and smaller in Greater Poland, eastern part of Mazovia, between Węgrów and Łuków, and in region of Tuchola Forest.

$\checkmark$. High emission from enteric fermentation and animal excreta and average emission from other sources - the type strongly con- 
Table 1. Characteristics of commune types due to $\mathrm{GHG}$ emission from agriculture ( $\mathrm{Mg} \mathrm{CO}_{2}$ eq/year)

\begin{tabular}{|c|c|c|c|c|c|c|c|}
\hline Type & Coefficient & $\begin{array}{c}\text { Enteric } \\
\text { fermentation }\end{array}$ & $\begin{array}{l}\text { Animal } \\
\text { faeces }\end{array}$ & $\begin{array}{c}\text { The use } \\
\text { of agricultural } \\
\text { soils }\end{array}$ & $\begin{array}{c}\text { The burning } \\
\text { of plant } \\
\text { residues }\end{array}$ & Total & $\begin{array}{l}\text { Number } \\
\text { of communes }\end{array}$ \\
\hline \multirow{3}{*}{ I } & \multirow{3}{*}{$\begin{array}{l}\text { average } \\
\sigma \\
\vee \\
\end{array}$} & $36,145.74$ & $173,782.58$ & $79,541.53$ & 5.27 & 289,475 & \multirow{3}{*}{1} \\
\hline & & 0.00 & 0.00 & 0.00 & 0.00 & 0 & \\
\hline & & 0.00 & 0.00 & 0.00 & 0.00 & 0 & \\
\hline \multirow{3}{*}{$\|$} & average & $8,039.16$ & $2,371.46$ & $73,008.45$ & 8.01 & 83,427 & \multirow{3}{*}{10} \\
\hline & $\sigma$ & $6,333.59$ & $2,640.94$ & $23,440.61$ & 3.80 & 32,419 & \\
\hline & V & 78.78 & 111.36 & & 47.47 & 270 & \\
\hline \multirow{3}{*}{ III } & average & $39,920.92$ & $9,573.53$ & $16,828.74$ & 2.64 & 66,326 & \multirow{3}{*}{35} \\
\hline & $\sigma$ & 6314.84 & $3,181.19$ & $3,806.90$ & 1.58 & 13,305 & \\
\hline & V & 15.82 & 33.23 & 22.62 & 59.68 & 131 & \\
\hline \multirow{3}{*}{ IV } & average & $23,191.41$ & $9,426.09$ & $14,091.65$ & 5.23 & 46,714 & \multirow{3}{*}{102} \\
\hline & $\sigma$ & $4,208.27$ & $6,473.72$ & $4,308.01$ & 4.67 & 14,995 & \\
\hline & V & 18.15 & 68.68 & 30.57 & 89.23 & 207 & \\
\hline \multirow{3}{*}{ V } & average & $14,568.89$ & $6,047.67$ & $9,442.83$ & 4.74 & 30,064 & \multirow{3}{*}{221} \\
\hline & $\sigma$ & $2,830.42$ & $3,238.86$ & $2,512.40$ & 3.86 & 8,586 & \\
\hline & V & 19.43 & 53.56 & 26.61 & 81.49 & 181 & \\
\hline \multirow{3}{*}{ VI } & average & $5,373.59$ & $3,116.20$ & $13,920.66$ & 7.11 & 22,418 & \multirow{3}{*}{80} \\
\hline & $\sigma$ & $2,897.95$ & 2615.68 & $4,138.73$ & 5.83 & 9,658 & \\
\hline & V & 53.93 & 83.94 & 29.73 & 82.08 & 250 & \\
\hline \multirow{3}{*}{ VII } & average & $7,986.65$ & $3,794.30$ & $6,547.35$ & 4.05 & 18,332 & \multirow{3}{*}{419} \\
\hline & $\sigma$ & $1,846.06$ & $1,835.62$ & $1,554.71$ & 2.91 & 5,239 & \\
\hline & V & 23.11 & 48.38 & 23.75 & 72.01 & 167 & \\
\hline \multirow{3}{*}{ VIII } & average & $3,538.10$ & $1,804.37$ & $4,710.59$ & 3.32 & 10,056 & \multirow{3}{*}{701} \\
\hline & $\sigma$ & $1,328.72$ & $1,042.30$ & $1,461.78$ & 3.09 & 3,836 & \\
\hline & V & 37.55 & 57.77 & 31.03 & 93.09 & 219 & \\
\hline \multirow{3}{*}{ IX } & average & 863.55 & 507.25 & $1,831.48$ & 1.38 & 3,204 & \multirow{3}{*}{905} \\
\hline & $\sigma$ & 716.79 & 502.57 & $1,097.52$ & 1.98 & 2,319 & \\
\hline & V & 83.01 & 99.08 & 59.93 & 143.54 & 386 & \\
\hline \multirow{3}{*}{ Total } & average & $5,712.28$ & $2,583.48$ & $5,552.03$ & 3.07 & 13,851 & \multirow{3}{*}{2474} \\
\hline & $\sigma$ & $7,144.54$ & $4,641.61$ & 6323.24 & 3.36 & 18,113 & \\
\hline & V & 125.07 & 179.67 & 113.89 & 109.27 & 528 & \\
\hline
\end{tabular}

$\sigma$ - standard deviation; $V$ - coefficient of variation

Average emissions: $\quad$ highest very high high

$$
\text { low verylow lowest }
$$

Values of the coefficient of variation that

best constitute the types: $\quad 0-20 \quad 20-40 \quad 40-60$

(the closer 0 , the better they confirm the existence of the type)

stituted by emission from enteric fermentation and slightly less from the use of agricultural soils. Out of 221 communes of this type, most of them are located in the Suwałki Region, north-eastern Mazovia, Chełmno-Dobrzyń Land, Greater Poland,
Krajna, north of the Lublin Region, central part of Masuria and the Sępopolska Lowland.

VI. Very high emission from combustion of plant residues (in comparison to other communes) and high emission from the 


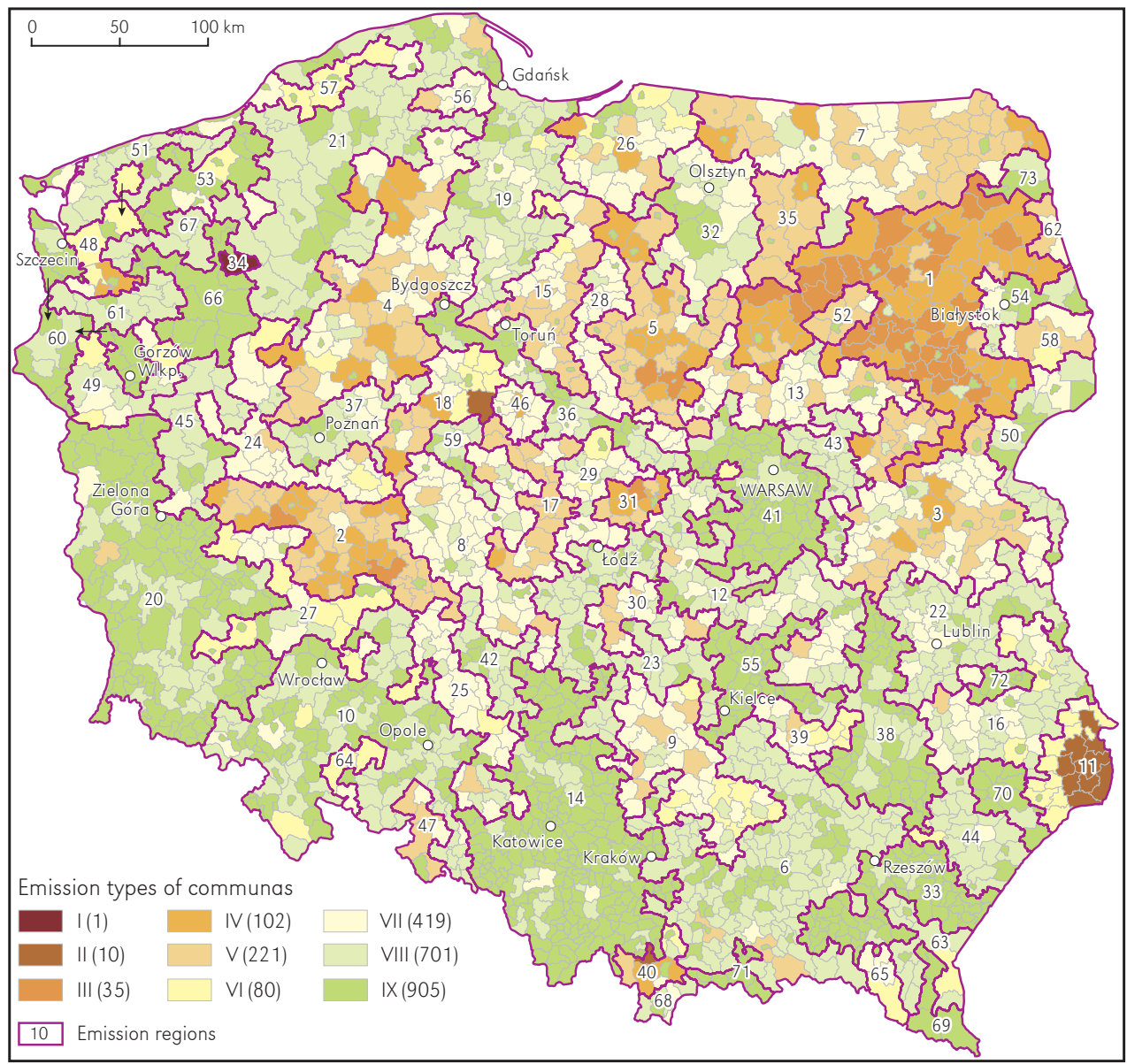

Figure 2. Distribution of types of communes separated on the basis of $\mathrm{GHG}$ emission from agriculture and regionalisation of this emission (73 regions)

use of agricultural soils, whereas average from other sources - the type average constituted by emission from the use of agricultural soils and quite poorly from enteric fermentation. This type is small in number (80 communes), dispersed throughout the country with concentrations of several neighbouring communes: the largest, surrounding type II communes, around Hrubieszów and smaller ones in central and western Pomerania, Lower Silesia, around Inowrocław, Opatów and in the south-eastern part of Ponidzie.

VII. Average emission from all the considered source groups - the type constituted by the emission from the use of agricultural soils, enteric fermentation and to a lesser extent from animal excreta. There are 419 communes of this type, located mainly in Greater Poland, the northern part of Masuria and southern Kurpie, Dobrzyń Land, Ponidzie, northern Lublin Region, southern Mazovia and Kashubia.

VIII. Low emissions from enteric fermentation and animal excreta and average emissions from other sources - the type on average is constituted by emissions from the use of agricultural soils and enteric fermentation. The group is very numerous, comprising of 701 communes located in different 
parts of the country, occupying the largest parts of Lower Powiśle, Pomerania, Lower Silesia, Łódź Land, Lesser Poland, central and southern Lublin Region and a belt of communes on the border with Belarus.

IX.The lowest emission from enteric fermentation and animal excreta and very low emission from the use of agricultural soils and combustion of plant residues (in comparison to other communes) - a poorly separated type, poorly constituted by the emission from the use of agricultural soils. The most numerous type (905 communes) and distributed throughout the country, but few in Greater Poland and in the north-eastern part of Poland. It dominates in Silesia, from Beskidy in the south to Radomsko in the north, in the Lubusz Land, around Warsaw, in the Podkarpacie Region and in the south-western part of Pomerania.

As a result of delimitation, 73 regions were obtained. Their numbering (1 - 73) results from the total GHG emission from agricultural sources in decreasing order. Five regions with highest emission, three of which are located in north-eastern Poland (PodlachiaKurpie, Southhern Podlachia, Iława-Raciąż) and the remaining two in Greater Poland and south-eastern part of Pomerania, generate $31 \%$ of agricultural GHG emission, occupying $16 \%$ of the country's area. In five regions, with lowest emissions, located mainly on the eastern border of Poland, $0.5 \%$ of GHG emissions are generated. In view of the sources of emission included in the study, it is highest in regions where agriculture dominates in the economic structure - cattle and pig breeding in particular, whereas it is lowest in regions with a predominance of forest management and industry usually accompanying the largest urban centres and agglomerations (Fig. 3). From the analysed source groups, two dominate (the use of agricultural soils and enteric fermentation), producing about $40 \%$ of $\mathrm{GHG}$ each. About $19 \%$ of the emission comes from animal excreta and the share of combustion of plant residues is negligible $(0.02 \%)$ and may be omitted from further analyses.
The surface areas of the regions are highly diversified. The largest - from $14,000 \mathrm{~km}^{2} \mathrm{t}$ o $16,000 \mathrm{~km}^{2}$ include the following regions: Podlachia-Kurpie (90 communes), LubuszŁużyce (125), Silesia-Beskidy-Radomsko (213), Lesser Poland (146) and Lower Silesia (130). The smallest (from 550 to $800 \mathrm{~km}^{2}$ ) are: Rejowiec Region (7 communes), Tatry Region (6), Lipsko Region (4), Pieniny-Muszyna Region (9) and Augustów Region (3) and the region consisting of one commune Wierzchowo $\left(236.5 \mathrm{~km}^{2}\right)$. The most populous regions, however, with relatively low emissions, include the following: Silesia-BeskidyRadomsko (5.27 million inhabitants) and Warsaw Region (3 million in 91 communes), followed by Lesser Poland (2.63 million) and Lower Silesia (2.64 million). Other than these, the regions of Łódź-Częstochowa and Lubusz-Łużyce are also highly populated. The least populated regions are: Wierzchowo commune (4.3 thousand people), Sanok-Ustrzyki Region (15.6 thousand) and Pieniny-Muszyna, Rymanów, Augustów and Rejowiec (each with 31 to 36 thousand inhabitants).

The needs for action to reduce GHG emissions result from the size and structure of the emissions, first of all in total terms, but also from taking into account the relative size of the emission, expressed by indicators related to the population and surface area of the regions (Fig. 4). Apart from the five regions mentioned above with the highest emissions, it is also worth taking note of the other regions where, not only the total emissions are significant, but also the indicators outlined above reach largerthan-average values. These, in particular, include such regions as: Hrubieszów, Łowicz, eastern Greater Poland, Radziejów, Kuyavia and Tuszyn-Opoczno (with the exception of the first one, they are located in the central part of the country). In this context, it is also worth noting the following regions: northern Masuria, Ponidzie, Ciechanów-Kurpie and Chełmno Land. The Wierzchowo region is a recordbreaking region in terms of indicator values. The annual GHG emission from agriculture was estimated there at $67.2 \mathrm{Mg} \mathrm{CO}$ eq per 


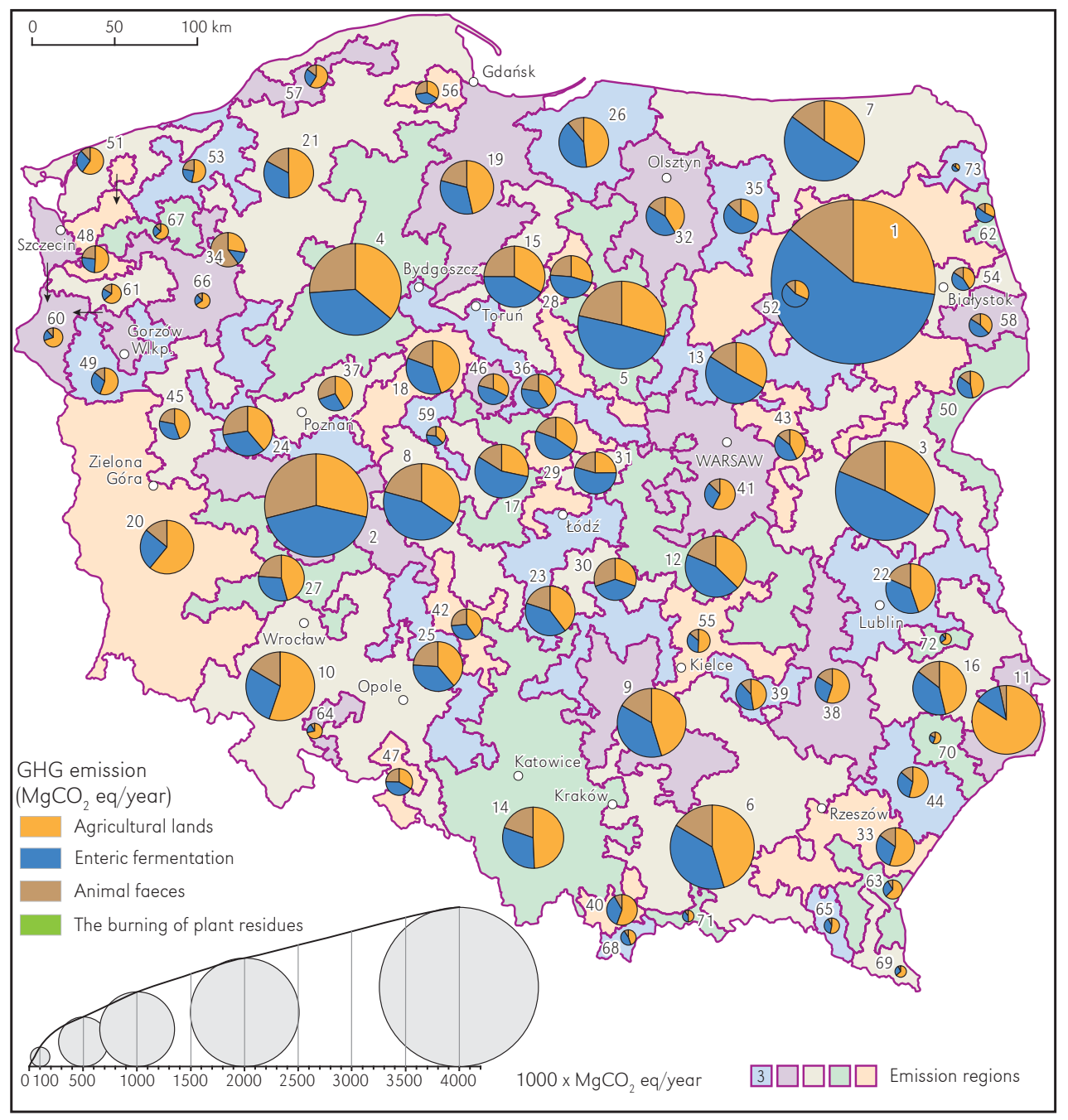

Figure 3. Size and structure of GHG emission sources from agriculture by emission regions

capita and $1224 \mathrm{Mg} \mathrm{CO}$ eq $/ \mathrm{km}^{2}$ and is respectively 11 and 3.7 times higher than the second regions in this respect (Podlachia-Kurpie and Łowicz).

8 regions make up the group of regions with the highest priority of GHG emission reduction measures, while 17 regions are characterised by a high priority. Taking into account the volume of emissions per capita and surface area, 5 regions each have highest priority of measures, and 16 regions each have high priority (Fig. 5).
On the basis of the typology of regions, 12 types of regions were identified owing to the structure of emission (Fig. 5):

A. Very high share of emission from agricultural soils, low share from enteric fermentation and very low share from animal excreta - 1 region (Hrubieszów).

B. High share of emission from agricultural soils, low or average from enteric fermentation and very low or low from animal excreta - 2 regions (Szczecin-Gorzów and Ziębice). 


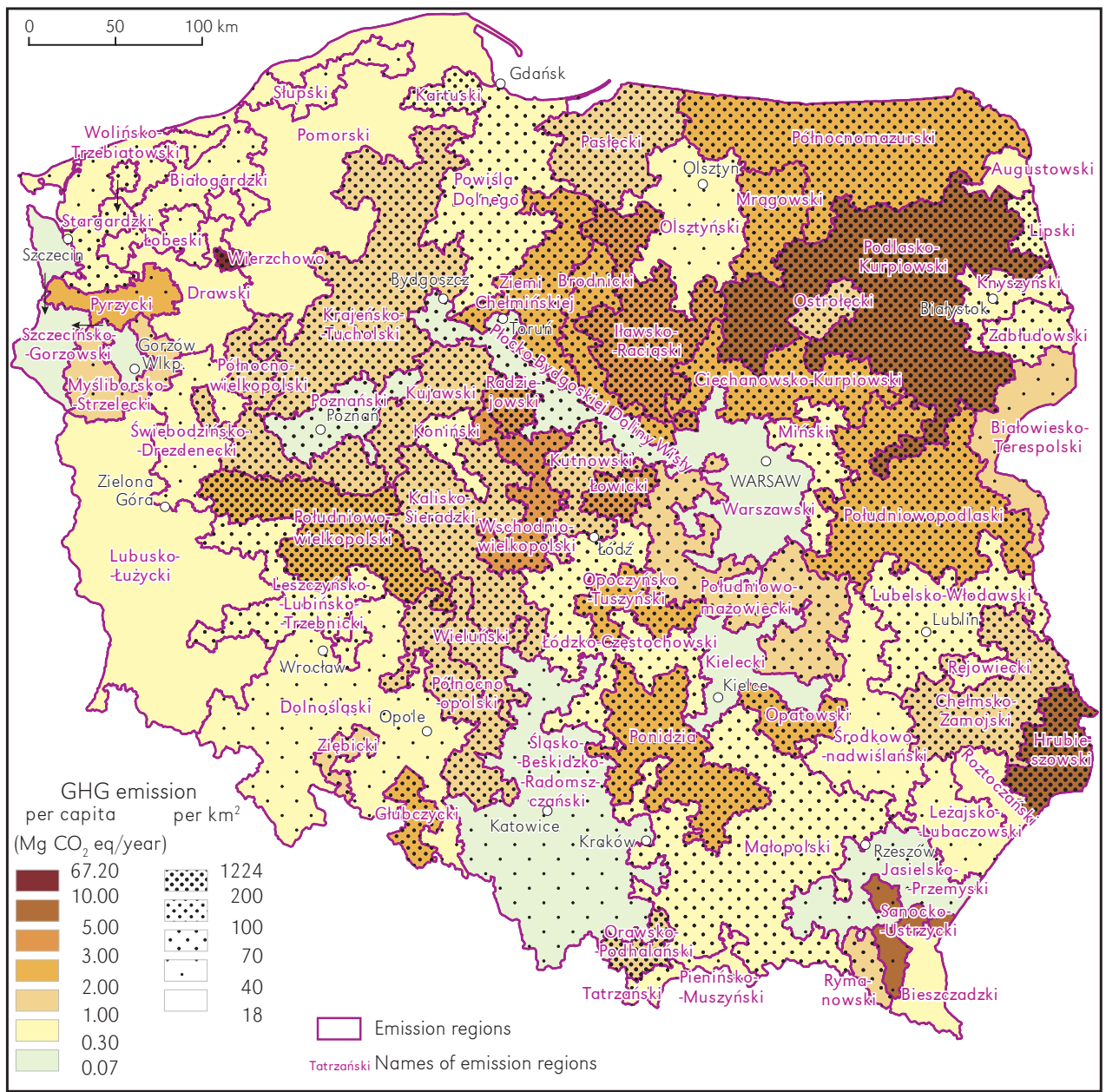

Figure 4. GHG emissions from agriculture in relation to the population and area of regions

C. Significant share of emission from agricultural soils, average from enteric fermentation and very low or low from animal excreta - 3 regions (Orawa-Podhale, Kielce and Rymanów).

D. Significant share of emission from agricultural soils, average from enteric fermentation and low or average from animal excreta -15 regions, dominating in the western and south-eastern part of the country.

E. Significant share of emissions from agricultural soils, low or average from enteric fermentation and very low or low from livestock manure - 3 regions (Pyrzyce, SanokUstrzyki and Bieszczady).
F. Medium share of emission from agricultural soils, significant from enteric fermentation and low from animal excreta - occurring only in the North Masuria Region.

G. Medium share of emission from agricultural soils and enteric fermentation and average share from animal excreta - 11 regions, located mainly in Greater Poland and the central part of the country.

H. Medium share of emissions from agricultural soils and enteric fermentation and very low and low share of emissions from animal excreta - 17 regions, located mostly in Lesser Poland, Lublin Region, 


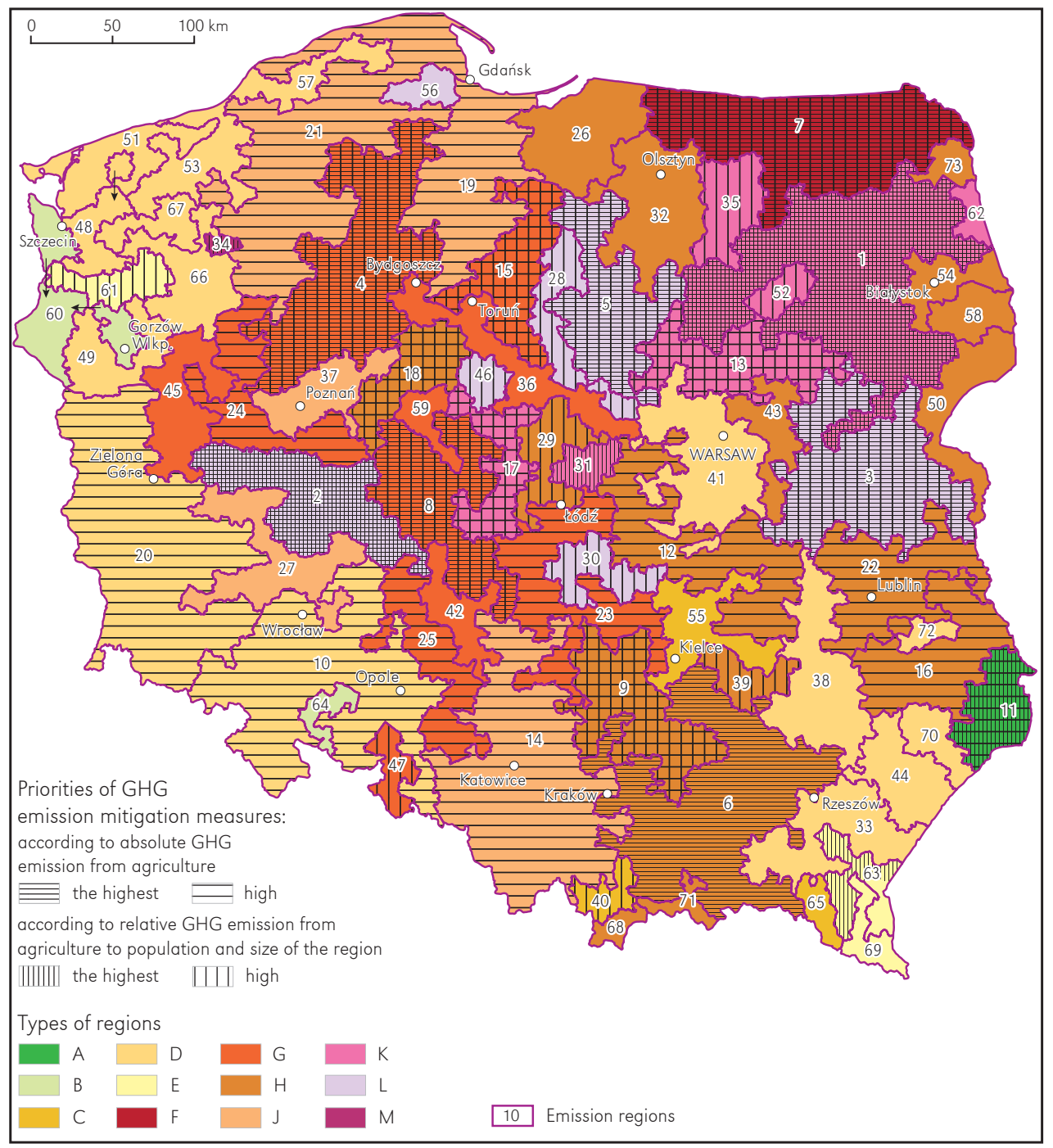

Figure 5. Types of regions due to the structure of GHG emission from agriculture and priorities of activities limiting GHG emission determined on the basis of absolute and relative size of GHG emission

on the eastern border of the country and in Warmia.

J. Medium share of emission from agricultural soils, average from enteric fermentation and low or average from animal excreta - 5 regions, typical of the lands of former Prussian rule.

K. Average share of emission from agricultural soils, significant from enteric fermentation and low or average from animal excreta
- 7 regions, characteristic for northern Mazovia and Podlachia.

L. Average share of emission from agricultural soils, average share from enteric fermentation and low or average share from animal excreta -7 regions, situated mainly in the central latitudinal belt of the country from Greater Poland to Podlachia.

M. The commune of Wierzchowo with an average share of emission from agricultural 
soils, low from enteric fermentation and high from animal excreta.

As a result of the imposition of the above typology on the regions indicated as priority for measures to reduce GHG emission, determined earlier on the basis of the analysis of absolute and relative size of emissions, the picture presented in Fig. 5 was obtained. It shows that the most urgent measures should be taken in regions of type K (Podlachia-Kurpie, Ciechanów-Kurpie, eastern Greater Poland), L (southern Greater Poland, southern Podlachia and Iława-Raciąż) and G (Krajna-Tuchola, Kalisz-Sieradz, Chełmno Land), as well as in regions of type A and F, with single regions (Hrubieszów and northern Masuria). In planning the action, one should also pay attention to Ponidzie and Wierzchowo commune. On the other hand, regions with the lowest need for measures belonging primarily to types B and D and are located chiefly in Western Pomerania and south-eastern Poland. They also include the Warsaw Region. Numerous H-type regions in Warmia and along the eastern border of the country, also have little need for planned measures. In the course of emission reduction measures, one may also point out several regions where the emission from combustion of plant residues is slightly higher and amounts to about $0.1 \%$ in each case. These include the following regions: Szczecin-Gorzów, Pyrzyce, Ziembice, Łobez and Lower Silesia - all located in the western part of the country.

In order to reduce emissions from agricultural sources and increase $\mathrm{CO}_{2}$ absorption, it is necessary to strive primarily to fully utilise the potential of forestry and agricultural land to increase carbon sequestration in biomass and soil, to bring organic matter into the soil with simultaneous reduction of soil losses, to optimise storage, transport and distribution systems for livestock manure in fields and their appropriate management, to make extensive use of agricultural activity and agri-food processing for the development of renewable energy (including biogas and biofuel production), as well as to significantly improve energy efficiency and increase the share of renewable energy in plant production and breeding (Wiśniewski, 2015; Wiśniewski \& Kistowski, 2017). The achievement of these objectives requires the implementation of appropriate mitigation measures, adapted to local environmental conditions and the different size and structure of emissions in individual regions (Tab. 2).

In the Hrubieszów Region, which is distinguished, in the country, by particularly high emission from agricultural soils, there is an urgent need to undertake mitigation measures, including first of all the application of good practices when farmers use organic fertilizers as an alternative to mineral fertilizers and the use of organic waste not used in agricultural holdings for energy production as an element of a circular economy (Case, Oelofse, Hou, Oenema, \& Jensen, 2017). Action is also urgently needed to increase soil carbon sequestration. Research on good agricultural practice shows that soil management strategies aimed at carbon sequestration are most effective when accompanied by erosion protection, maintain a good structure and balance in nutrient, and the use of intercrops and undersown crops with a positive soil organic matter reproduction rates (Cong, Hoffland, Li, Janssen, \& Van Der Werf, 2015; Nadeu, Gobin, Fiener, van Wesemael, \& van Oost, 2015; Borrelli, Paustian, Panagos, Jones, Schütt, \& Lugato, 2016). Urgent action is also needed in C, E and G regions in order to introduce organic matter into the soil while reducing soil losses (e.g. by increasing biomass production, using organic fertilisers, introducing grassland and applying appropriate agricultural practices). In regions characterised by a relatively high share of marginal land (mainly types $C$ without Pyrzyce Region, $E, H$ and $M$ ), the use of set-aside land or fallow land and uncultivated land for the cultivation of energy crops should be aimed at. Their cultivation on marginal land may provide many ecosystem services, including biomass production, limiting soil erosion, soil carbon sequestration and soil properties improvement (Davis et al., 2010; Gelfand, Zenone, Jasrotia, Chen, Hamilton, \& Robertson, 2011; 
Table 2. Proposed directions of mitigation actions in particular types of regions

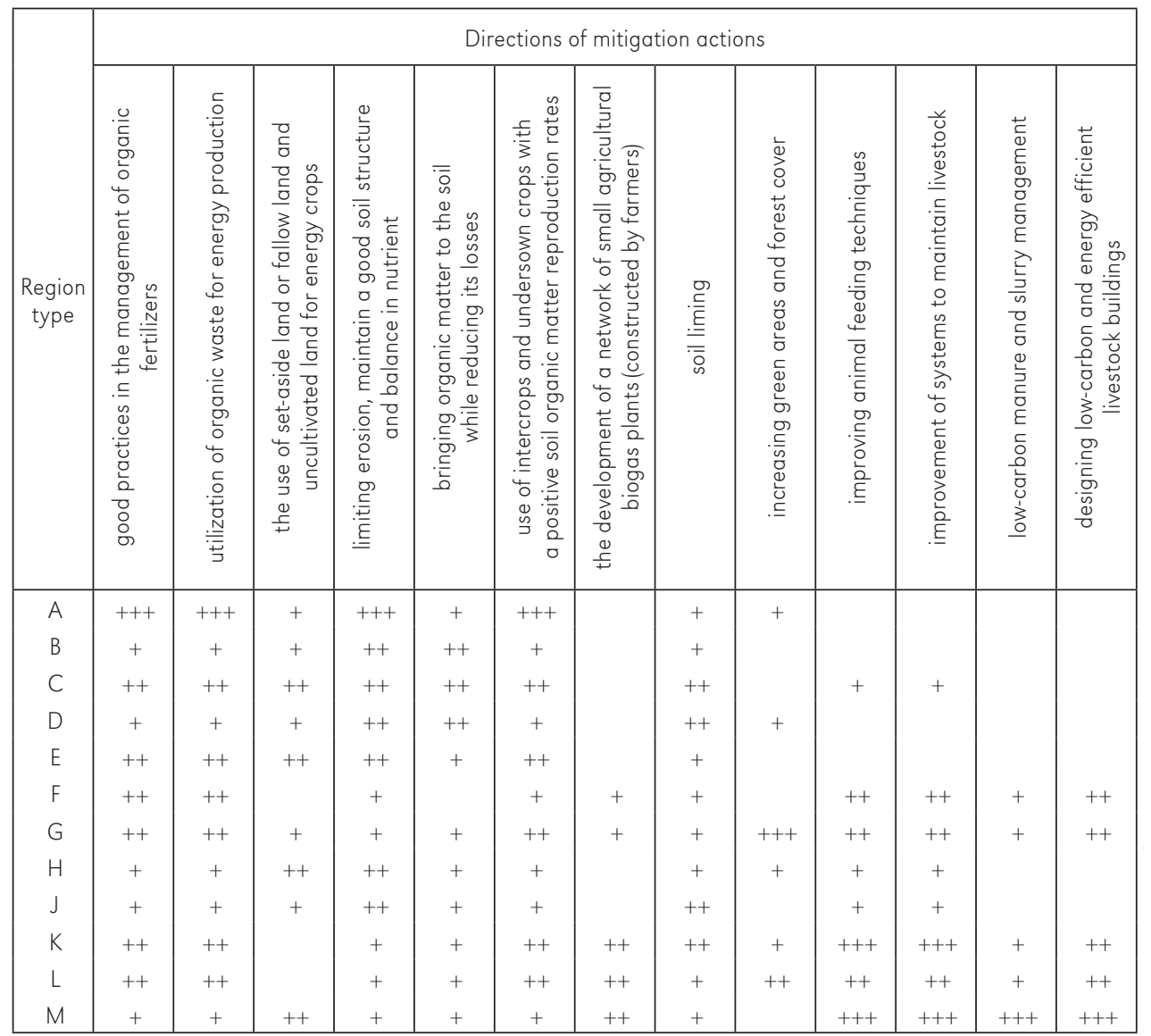

mitigation actions: +++ very urgent, ++ urgent, + average urgent

Blanco-Canqui, 2016). However, the invasive threat of some energy crops and the profitability of crops need to be more widely recognised. In regions with a significant or high share of emissions from enteric fermentation and livestock manure (types F, K and M), there is an urgent need to apply and promote good practices and low-carbon technologies in the agri-food sector, including improving animal feeding techniques and maintenance systems, low-carbon manure and slurry management and designing low-carbon and energy efficient livestock buildings taking into account the best available techniques (Loyon et al., 2016). However, as emphasized by Bennetzen, Smith, and Porter (2016), agricultural GHG emissions can only be reduced to a certain level and a simultaneous focus on other parts of the food-system is necessary to increase food security whilst reducing emissions.

\section{Conclusions}

Advanced statistical analyses of the results of mathematical modelling of GHG emission from agricultural sources at the local level in Poland has made it possible to distinguish 9 types of communes, diversified in terms of the size and structure of the emission. As a result of regionalisation based on the principle of maximum similarity of types 
belonging to particular regions of communes, 73 regions were obtained. Five of them, with the highest emission, generating 31\% of the national GHG emission and occupying 16\% of the country's area, are located in northeastern Poland, Greater Poland and southeastern part of Pomerania. On the other hand, the five regions with the lowest emissions are located, mainly, on the eastern border of Poland. In terms of GHG emissions from agriculture with respect to the population and surface area, the Wierzchowo Region reaches record levels. High values of these indicators are also characteristic for the regions of Hrubieszów, eastern Greater Poland, Radziejów, Kuyavia and Tuszyn-Opoczno.

In the group of regions with the highest priority for action to reduce GHG emissions, on account of its total value, there are 8 regions, while 17 regions have a high priority. Taking into account the volume of emissions per capita and area, 5 regions each have the highest priority for action and 16 regions each have a high priority for action.

Based on the typology of regions, 12 types of regions were identified due to the structure of emissions. The highest priority of measures limiting GHG emission from agriculture is given to regions of type $K$ (Podlachia-Kurpie, Ciechanów-Kurpie, eastern Greater Poland), L (southern Greater Poland, southern Podlachia and Iława-Raciąż) and G (Krajna-Tuchola, Kalisz-Sieradz and Chełmno Land), as well as to regions of type $A$ and $F$, with single units (Hrubieszów and northern Masuria). When planning protection measures, one should also pay attention to Ponidzie and Wierzchowo commune. Regions with the lowest need for measures belong, primarily, to types $B$ and $D$ and are located mainly in Western Pomerania and south-eastern Poland. They also include the Warsaw Region. Numerous $\mathrm{H}$-type regions in Warmia and along the eastern border of the country also have little need for mitigation measures.

Adaptation of appropriate directions of mitigation actions to environmental conditions and the differentiated size and structure of emissions in particular regions will allow for more effective reduction of these emissions and their negative effects on the atmosphere, climate and other elements of the ecosystems. In the regions with the highest priority of mitigation measures, particular attention should be paid to the use of the potential of agriculture and rural areas (including forests) to increase carbon sequestration in biomass and soil and to reduce GHG emissions, as well as the use of agricultural activity and agri-food processing together with wood biomass for the development of renewable energy, including the production of biogas and biofuels. Furthermore, regions with a significant or high proportion of emissions from enteric fermentation and animal excreta also require very urgent action to improve, in particular, animal feeding techniques and animal husbandry systems, low-carbon manure and management of slurry and the use of best available techniques in designing low-carbon and energy efficient livestock buildings.

\section{Editors' note:}

Unless otherwise stated, the sources of tables and figures are the authors', on the basis of their own research.

\section{References}

Bennetzen, E.H., Smith, P., Porter, J.R. (2016). Decoupling of greenhouse gas emissions from global agricultural production: 1970-2050. Global Change Biology, 22, 763-781. https://doi.org/10.1111/ gcb. 13120

Blanco-Canqui, H. (2016). Growing dedicated energy crops on marginal lands and ecosystem services. Soil Science Society of America Journal, 80(4), 845-858. https://doi.org/10.2136/sssaj2016.03.0080 
Borrelli, P., Paustian, K., Panagos, P., Jones, A., Schütt, B., Lugato, E. (2016). Effect of good agricultural and environmental conditions on erosion and soil organic carbon balance: A national case study. Land Use Policy, 50, 408-421. https://doi.org/10.1016/j.landusepol.2015.09.033

Case, S.D.C., Oelofse, M., Hou, Y., Oenema, O., Jensen, L.S. (2017). Farmer perceptions and use of organic waste products as fertilisers - A survey study of potential benefits and barriers. Agricultural Systems, 151, 84-95. https://doi.org/10.1016/j.agsy.2016.11.012

Cong, W.F., Hoffland, E., Li, L., Janssen, B.H., Van Der Werf, W. (2015). Intercropping affects the rate of decomposition of soil organic matter and root litter. Plant and Soil, 391(1-2), 399-411. https://doi.org/10.1007/s11104-015-2433-5

Davis, S.C., Parton, W.J., Dohleman, F.G., Smith, C.M., Del Grosso, S., Kent, A.D., DeLucia, E.H. (2010). Comparative biogeochemical cycles of bioenergy crops reveal nitrogen-fixation and low greenhouse gas emissions in a Miscanthus $\times$ giganteus agro-ecosystem. Ecosystems, 13(1), 144-156. https://doi.org/10.1007/s10021-009-9306-9

Gaczek, W.M., Helpa, M., Kasprzyk, A. (1980). Niehierarchiczna analiza skupień - nowa metoda klasyfikacji zjawisk społeczno-gospodarczych. Ruch Prawniczy, Ekonomiczny i Socjologiczny, 42(2), 143-162.

Gelfand, I., Zenone, T., Jasrotia, P., Chen, J., Hamilton, S.K., Robertson, G.P. (2011). Carbon debt of Conservation Reserve Program (CRP) grasslands converted to bioenergy production. Proceedings of the National Academy of Sciences of the United States of America, 108(33), 13864-13869. https://doi.org/10.1073/pnas.1017277108

Instytut na Rzecz Ekorozwoju. (2015). Pilotażowy program niskowęglowego rozwoju powiatu starogardzkiego. Warszawa: Fundacja Instytut na rzecz Ekorozwoju.

IPCC. (2000). Good practice guidance and uncertainty management in National Greenhouse Gas Inventories. Hayama: Intergovernmental Panel on Climate Change.

IPCC. (2006). 2006 IPCC guidelines for National Greenhouse Gas Inventories. Hayama: Intergovernmental Panel on Climate Change.

IPCC. (2013). Climate change 2013. The Physical Science Basis. Contribution of Working Group I to the Fifth Assessment Report of the Intergovernmental Panel on Climate Change. Cambridge: Intergovernmental Panel on Climate Change.

Kisielińska, J. (2009). Bezwzorcowa klasyfikacja obiektów w ekonomice rolnictwa. Zeszyty Naukowe SGGW w Warszawie. Problemy Rolnictwa Światowego, 8(23), 104-115.

Kistowski, M., Myga-Piątek, U., Solon, J. (Eds.). (2018). Studia nad regionalizacją fizycznogeograficzna Polski. Prace Geograficzne, 266, Warszawa: Instytut Geografii i Przestrzennego Zagospodarowania im. Stanisława Leszczyckiego PAN.

KOBiZE. (2019). Poland's National Inventory Report 2019: Greenhouse Gas Inventory for 1988-2017. Warsaw: National Centre for Emission Management (KOBiZE).

Loyon, L., Burton, C.H., Misselbrook, T., Webb, J., Philippe, F.X., Aguilar, M., Doreau, M., Hassouna, M., Veldkamp, T., Dourmand, J.Y., Bonmati, A., Grimm, E., Sommer, S.G. (2016). Best available technology for European livestock farms: Availability, effectiveness and uptake. Journal of Environmental Management, 166, 1-11. https://doi.org/10.1016/j.jenvman.2015.09.046

Nadeu, E., Gobin, A., Fiener, P., van Wesemael, B., van Oost, K. (2015). Modelling the impact of agricultural management on soil carbon stocks at the regional scale: The role of lateral fluxes. Global Change Biology, 21(8), 3181-3192. https://doi.org/10.1111/gcb.12889

Ossowska, L. (2006). Typologia funkcjonalna obszarów wiejskich Pomorza Środkowego. Roczniki Naukowe Stowarzyszenia Ekonomistów Rolnictwa i Agrobiznesu, 8(4), 254-257.

Przewoźniak, M. (1987). Podstawy geografii fizycznej kompleksowej. Gdańsk: Uniwersytet Gdański.

Richards, M.B., Wollenberg, E., Buglion-Gluck, S. (2015). Agriculture's contributions to national emissions. CCAFS Info Brief. Copenhagen: CGIAR Research Program on Climate Change, Agriculture and Food Security (CCAFS). Retrieved from https://ccafs.cgiar.org/publications/agricultures-contribution-national-emissions\#.XSmb7kHVLIU [13 July 2019]. 
Richling, A. (1976). Analiza i struktura środowiska geograficznego i nowa metoda regionalizacji fizycznogeograficznej (na przykładzie województwa białostockiego). Warszawa: Wydawnictwo Uniwersytetu Warszawskiego.

Rutkowski, T. (1982). Metody taksonometryczne w badaniach regionalnych. Ruch Prawniczy, Ekonomiczny i Socjologiczny, 44(2), 147-156.

Szczuciński, P. (2017). Analiza skupień w badaniu struktury funkcjonalnej gmin na przykładzie województwa lubuskiego. Turystyka i Rozwój Regionalny, 8, 105-114. https://doi.org/10.22630/tirr.2017.8.23

Wiśniewski, P. (2015). Rolnictwo i obszary wiejskie w lokalnym planowaniu gospodarki niskoemisyjnej na przykładzie powiatu starogardzkiego. Woda-Środowisko-Obszary Wiejskie, 15(4), 69-81.

Wiśniewski, P. (2018). Ocena wielkości emisji gazów cieplarnianych ze źródeł rolniczych na poziomie lokalnym w Polsce. Rocznik Ochrona Środowiska, 20, 1811-1829.

Wiśniewski, P., Kistowski, M. (2017). Agriculture and rural areas in the local planning of low carbon economy in light of the idea of sustainable development - results from a case study in north-central Poland. Fresenius Environmental Bulletin, 26(8), 4927-4935.

Wiśniewski, P., Kistowski, M. (2018). Assessment of greenhouse gas emissions from agricultural sources in order to plan for needs of low carbon economy at local level in Poland. Geografisk Tidsskrift-Danish Journal of Geography, 118(2), 123-136. https://doi.org/10.1080/00167223.2018.1436447

Wiśniewski, P., Kistowski, M. (2019). Local-level agricultural greenhouse gas emissions in Poland. Fresenius Environmental Bulletin, 28(3), 2255-2268. 